NBER WORKING PAPER SERIES

\title{
ON THE INTERNATIONAL FINANCIAL ARCHITECTURE: INSURING EMERGING MARKETS
}

\author{
Ricardo J. Caballero \\ Working Paper 9570 \\ http://www.nber.org/papers/w9570 \\ NATIONAL BUREAU OF ECONOMIC RESEARCH \\ 1050 Massachusetts Avenue \\ Cambridge, MA 02138 \\ March 2003
}

This article is based on "The Future of the IMF," prepared for the AEA session: "The Future of the IMF and World Bank," Washington D.C., January 2003. I thank Olivier Blanchard, Eduardo Borensztein, Fernando Broner, Jose De Gregorio, Martin Feldstein, Stanley Fischer, Arvind Krishnamurthy, Bengt Holmstrom, Paolo Mauro, Allan Meltzer, Stavros Panageas and Nicholas Stern for their comments to that paper. I also thank the National Science Foundation for financial support.The views expressed herein are those of the authors and not necessarily those of the National Bureau of Economic Research.

(C)2003 by Ricardo J. Caballero. All rights reserved. Short sections of text not to exceed two paragraphs, may be quoted without explicit permission provided that full credit including Cnotice, is given to the source. 
On the International Financial Architecture: Insuring Emerging Markets

Ricardo J. Caballero

NBER Working Paper No. 9570

March 2003

JEL No. E0, E5, E6, F0, F3, G1, G2, O2

\begin{abstract}
$\underline{\text { ABSTRACT }}$
In spite of significant institutional and macroeconomic reforms over the last decade or two, capital flows to developing economies remain highly volatile. In 1996, net private capital flows to emerging markets reached US\$230 billions; by 1997 these flows had been cut in half; by 1998 halved again; and after a mild recovery during 1999, flows fell in 2000 and 2001 to slightly over one-tenth the level of 1996. These reversals in capital flows have enormous economic and social costs for developing economies. For "well behaved" countries, a significant share of these fluctuations is triggered by events that are outside their direct control, and often outside the control of emerging markets as a whole. Building on this observation, this paper highlights some of the desirable features of insurance and hedging instruments against capital flow volatility, and discusses steps to facilitate the creation of these markets.
\end{abstract}

Ricardo J. Caballero

Department of Economics

MIT

E52-252

Cambridge, MA 02142

and NBER

caball@mit.edu 
As a result of domestic and external factors, capital flows to emerging market economies are highly volatile. All too often, these economies experience severe financial distress, which in some instances lead them to the country-equivalent of bankruptcy. Recently, the IMF and the U.S. Treasury have come up with plans to facilitate an orderly restructuring of liabilities during periods of sovereigns' distress. The IMF advocates an International Bankruptcy Procedure, using Chapters 9 and 11 from U.S. municipal and corporate bankruptcy laws as the benchmark. The U.S. Treasury wants mandatory collective action clauses (CACs) on all sovereign bonds.

However, by focusing almost exclusively on the needs of countries undergoing deep crises ---highly illiquid and "bankrupt" economies--- these reform proposals have left unaddressed a significant fraction of the costs associated with capital flows reversals. An important share of these costs are borne by countries that experience deep contractions but do not undergo full blown crises; and even for those countries that do fall into deep crises, many of the costs are incurred well before the run-phase of the crisis develops. In fact, the latter often is just the final stage of a prolonged and politically thorny economic period of sharply reduced access to international capital markets. Surely, the anticipation of a more orderly workout and access to a few credit lines should the crisis phase arrive, also would (by backward induction) eliminate some of the costs that precede these events. But this benefit is indirect only and relies on a chain of reasoning that requires more rationality and trust in the new system than financial markets in panic mode typically exhibit. Developing economies need a more direct and robust mechanism to deal with capital flow reversals. This is the starting point of the proposal summarized in this article: Emerging markets need instruments of hedging and insurance against capital flow reversals.

Because of its size, this has to be primarily a market solution. In the next pages I sketch a few ideas about which markets could be developed and what the role of the International Financial Institutions (henceforth, IFIs) could be in facilitating the creation and functioning of these markets. 


\section{Australia as a Benchmark}

In principle, one of the great virtues of financial markets is that they allow the borrower to decouple expenditure from temporary fluctuations in resources. This is extremely important for a small country in smoothing its business cycle and preventing wasteful disruptions of long-term projects. A breakdown in this service is particularly serious for an economy still catching up with the developed world, because this typically makes it a net borrower, even during normal times. Unfortunately, in emerging markets these breakdowns occur all too frequently.

A comparison of the experiences of Australia and Chile during the Asian/Russian crises isolates the problem well. Both Australia and Chile have very open economies with exports that are intensive in volatile commodities. Australia has deep domestic financial markets and links to international financial markets. Chile, while often used as an example among emerging economies for its good macroeconomic policy and institutional development, does not have the degree of financial development and links with international financial markets that Australia has.

The story of Australia during that Asian/Russian crisis is a textbook one. With most of its neighbors crumbling, its terms of trade experienced a significant decline. Seeing the potentially recessionary consequences of such a decline, the Central Bank of Australia loosened monetary policy. At the end of the day, neither consumers nor firms altered their plans. The entire adjustment was absorbed by a current account deficit that rose temporarily from 2 to 6 percent of GDP, and was financed by an increase in capital inflows.

The story of Chile has a similar beginning but a very different conclusion. As its terms of trade (essentially, the price of copper) deteriorated, Chile initially attempted to smooth things with macroeconomic policy, especially fiscal policy. But as the external conditions worsened, Chile's international capital markets began tightening. Despite very low levels of external debt, a current account deficit of more than 6 percent began to worry many observers. Resident (especially foreign) banks began pulling resources out of the country, and the currency soon was subject to repeated attacks. Monetary policy could not be used to soften the impact of the decline in terms of trade because it was locked into fending off the speculative attacks and attempting to slow down the sharp 
reversal in capital inflows. When all was said and done (by the end of 1999), the current account had turned into a surplus to accommodate the tight financial conditions and expenditure had declined by about 15 percent relative to its pre-shock trend. My back of the envelope calculations suggest that Chile's contraction was nearly ten times larger than it would have been if it had been able to count on unrestricted access to international financial markets. ${ }^{2}$

Many have argued that part of the Chilean adjustment problem was attributable to domestic policy rather than to a sudden stop in capital flows. Perhaps, but that is just a matter of degree of adjustment. This discussion clouds the more important point that prudent emerging economies often experience severe precautionary recessions when the possibility of an open crisis is too close for comfort. These deep precautionary recessions are part of the cost of living in an environment of volatile capital flows. They may be less "spectacular" than open crises are, but cumulatively (across countries and time) they account for a significant fraction of the costs of capital flows' volatility. Moreover, open crises often are preceded by long periods of precautionary recessions. And, at times, it is the social and political unrest that these periods cause that ends up triggering the full blown crises. If one could smooth these precautionary recessions, many of the crises would be prevented as well.

\section{Macro-Insurance}

Even before reaching the degree of development of Australia, emerging market economies could respond to external shocks nearly as smoothly as Australia does. But in order to do so, they need access to hedging and insurance instruments to guard against the disastrous events caused by volatile capital flows. For now, these economies are selfinsuring through costly accumulation of large international reserves and stabilization funds. Most individuals would be "underinsured" if they had to leave a million dollars aside for a potential automobile collision and the liabilities that would follow, rather than buying insurance against such event; countries are no different. Underinsurance is what greatly amplifies these countries' recessions.

\footnotetext{
${ }^{2}$ See Caballero (2001, 2003).
} 


\section{III.1 Hedging Markets}

Let us return to our main example, Chile. It does not take much insight to notice that its deep recessions and crises are linked closely to sharp declines in the price of copper. By now, this is an accepted reality for Chileans and foreigners alike. This needs not be the case, though. As I argued earlier, during extreme events the Chilean contractions are many times larger than they ought to be. The problem is not in the wealth impact of a decline in the price of copper, Chile's main export, but rather in the many rational and irrational reactions that such a decline generates on the part of domestic and foreign investors. It is the capital flows reversal that is behind the "disaster." In this context, it is apparent that Chile would benefit if it could insure or hedge against these disasters and that an instrument contingent on the price of copper would provide significant help along this dimension. (Actually, an even better instrument would be indexed to the price of copper and the high-yield spread. ${ }^{3}$ )

But, don't Chile and other commodity-exporter economies already do this through derivative markets? And doesn't the CCFL at the IMF provide some of that insurance as well? No. What CODELCO (Chile's state Copper company) and PEMEX (Mexico's state Oil company) and others do is to hedge some of the short-run revenue impact of fluctuations in the corresponding spot prices; in particular, they attempt to stabilize the impact of commodity price changes on the government's revenue. The CCFL does some of the same for poor economies. But this means stabilizing the daily "wiggles" and the direct effect of commodity prices on income flows, not the infrequent but much larger recessions triggered by the perverse reactions of capital markets to sharp declines in commodity prices and other distress indicators. Surely, hedging the income flows solves part of the financial shock by stabilizing the country's "collateral." But the markets' reactions to the price of the country's main commodity signal, especially when it comes at times of tight international financial markets, seems much larger than what countrycollateral models (with a fixed share of wealth as collateral) can explain.

Hedging the financial mechanism behind macroeconomic disasters is a bigger problem (perhaps ten times larger?) than what these countries now do, or what

\footnotetext{
${ }^{3}$ See Caballero (2003) for a proposal of this nature, and Caballero and Panageas (2003) for a formal quantitative framework to help designing these hedging strategies.
} 
conventional commodity-derivative markets can absorb at this time. For example, Chile could eliminate most ---if not all-- of its deep recessions by embedding into its external bonds a long-term put option, yielding US\$6-8 billion when the price of copper falls by more than two standard deviations for a few months. Of course, this example is only meant to be illustrative. The optimal design of such bonds would have other contingencies (including the high yield spread), several tranches, and take into account any possibility of (limited) price manipulation.

How much could the insurance component of the bond cost? If it was fairly priced, it could cost about $\$ 500$ million (lump sum). ${ }^{4}$ This is surely much less than the savings from the reduction in sovereign risk that would be attainable in the absence of the possibility of external crises, or the additional borrowing costs paid by the country to avoid short-run borrowing. And, it is certainly much cheaper than the precautionary recessions and other imperfect preventive measures that Chile currently undertakes, and for which it is praised.

But, of course, if Chile were to go to the markets to place such bonds, they would cost Chile far more than "fair" price. Today, there is no natural market for such instruments, and the corresponding derivatives markets would not suffice to cover the position of the writer of the option.

This situation can change, very much as the market for (natural) catastrophebonds in developed economies has changed over the last decade. The IFIs could foster this development. They could force troubled economies to swap their debt for contingent bonds and could subsidize well-behaved countries to do so voluntarily, taking the lead. Just as the restructuring of the bank loans caught in the debt crisis of the 1980s led to the development of the bond market for emerging economies, perhaps the forthcoming restructuring of Argentina's sovereign bonds can be used as an opportunity to create some markets for contingent bonds. And as the bond markets begin to reopen for the best emerging economies, this can be an opportunity for the IFIs to encourage and help them to restructure their liabilities with built-in contingencies.

Is Chile unique in terms of the causes of its external crises, and thus not a useful benchmark? Not really. It is true that Chile is very special in terms of the great precision

\footnotetext{
${ }^{4}$ See Caballero and Panageas (2003) for such calculations.
} 
of its capital-flow-reversal indicators. But most emerging economies have some indicators that could form the basis for such a strategy. For example, in the case of Mexico, a combination of the price of oil and U.S. GDP growth would be a good starting point; or Brazil, a high-yield index together with the price of coffee; Russia could build on the price of oil and a high-yield index; Korea on the price of semiconductors and the NASDAQ; and so on. ${ }^{5}$

Finally, it is important to stress that these markets are not aimed at solving crises caused by domestic factors. The insurance and hedging instruments are to be contingent on factors that are not controlled too easily by the individual country. Otherwise, moral hazard and specific knowledge of the countries become relevant issues, and that requires more expensive and scarce informed-capital. Issuing external debt in local currency, while extremely appealing on insurance grounds, is unlikely to provide the solution in the magnitude required, precisely because it fails this requirement.

\section{III.2 Asset Class Protection}

Who in the private sector could provide the insurance and become the hedging counterpart? The most obvious answer is the specialists in emerging markets. This is a starting point but is not ideal as a long term solution. Specialists are needed for information-intensive funding. Their information is particularly valuable when a country is in distress and nobody else wants to fund it. If specialists were to be the insurance providers, then they would see their resources shrink precisely when they are needed the most. This would not only curtail their ability to arbitrage (and finance) the high-return opportunities that a country in distress offers, but also could create the potential for "contagion" and collapses of the "asset class."

Since the hedging and insurance instruments I have discussed here are contingent on observable variables -- such as the price of copper and oil, developed economies' GDP, high-yield spreads, etc. -- there is no need for emerging markets or country-specific expertise to invest in such instruments. These risks can be decoupled entirely from the

\footnotetext{
${ }^{5}$ Interestingly, among the countries involved in the recent wave of crises one observes that the terms of trade of Thailand, Korea, Russia (especially), Brazil, Turkey and Argentina, declined sharply before and during their corresponding periods of turmoil.

${ }^{6}$ See Krishnamurthy (2003) for a model of amplification and shortages in insurance capital.
} 
risks of the underlying emerging economy issuer. One structure that would allow for such decoupling is Collateralized Debt Obligations (CDO). A CDO could purchase a diversified portfolio of emerging markets' contingent bonds and issue several tranches of bonds. The most senior of these bonds could absorb the explicit contingency but not the default risk. Specialists could take the latter through the mezzanine and subordinated debt/equity tranches. Ideally, global pension funds and insurance companies would invest on the senior tranches and hence provide the insurance against shocks that do not depend on the country's actions.

The literature emphasizes moral hazard and other deliberate actions by governments as a source of market segmentation and the need for specialists. But there is a more basic and pervasive reason for specialists: lack of understanding of the workings of developing economies and fears about local policymakers' competence. This is yet another reason for why local-currency-denominated debt is unlikely to catch the attention of broad markets for now.

Emerging markets (EM) CDOs already exist ---although, as far as I know, not with the contingency that is at the core of this proposal--- but they are in their infancy and undervalued. They typically require significantly more equity and are able to generate far fewer prime tranches than comparable U.S. high yield backed CDOs. The IFIs could play a role here as well, perhaps by directly investing in the subordinate-debt/equity tranche of these new Contingent-EM CDOs. Ex-post assistance lending could be done through the CDOs as well. These investments not only would yield direct benefits to emerging markets but also would be highly leveraged by the private sector --- a goal in itself in all the recent IFIs-reform reports. ${ }^{7}$ In addition, the IFI's participation in such activity would help to reduce the current undervaluation of this asset-backed investment by improving the emerging markets' expertise and the information available to the CDO's asset managers, as well as the monitoring of these managers. The IFIs also could use the mandates of the CDOs they invest in, to incentivize good reporting and accounting standards from emerging markets' corporations and governments.

\footnotetext{
${ }^{7}$ See Williamson (2000) for a summary of many of these resports.
} 
This structure also would have the virtue of leveraging the informed investors' capital without destroying their incentives in the process -- something akin to the insurance and reinsurance split in the catastrophe insurance market.

\section{Final Remarks}

In many instances, crises are non-contractible. They may arise from totally unexpected events or from domestic misbehavior and blunders. Adequately managed, a country's bankruptcy can be thought of as an ex-ante insurance arrangement for these illspecified non-contractible shocks.

However, the thesis of this proposal is that there is a lot more that is potentially contractible than seems to have been acknowledged. Even in the best managed emerging economies, aggregate risk management is being done with stone-age instruments and methods. With contingent markets: a) many crises would be stopped well before they develop; b) the costly self-insurance measures and deep precautionary recessions experienced by prudent emerging market economies would be reduced significantly; and c) much of this would be done by the private rather than the official sector.

Unfortunately, there are too many free-rider problems for these markets to emerge without a concerted effort. And once this happens, it also will be essential to ensure that the new insurance is not undone by the local government and private sector. This peril can be prevented with complementary monetary and fiscal rules tightly integrated with the insurance mechanism. ${ }^{8}$

\footnotetext{
${ }^{8}$ See Caballero and Krishnamurthy (2002a,b and 2003).
} 


\section{References}

Caballero, R.J., Macroeconomic Volatility in Reformed Latin America: Diagnosis and Policy Proposals. Washington, D.C.: Inter-American Development Bank, 2001.

, "Coping with Chile's External Vulnerability: A Financial Problem," in Central Banking, Analysis, and Economic Policies, Vol 6, Banco Central de Chile, 2003.

and A. Krishnamurthy, "A Vertical Analysis of Monetary Policy in Emerging Markets." MIT mimeo, March 2002a.

and , "A Dual Liquidity Model for Emerging Markets," American Economic Review, Papers and Proceedings, May 2002b.

and ___ "Inflation Targeting and Sudden Stops," MIT mimeo, February 2003.

and S. Panageas, "Hedging Sudden Stops and Precautionary Recessions: A Quantitative Approach,” MIT mimeo, February 2003.

Krishnamurthy, A. "Collateral Constraints and the Amplification Mechanism," forthcoming in Journal of Economic Theory, 2003.

Williamson, J., "The Role of the IMF: A Guide to the Reports," International Economics Policy Briefs, IIE, May 2000. 